\title{
Recorregut de recerca geològica i mineralògica per la comarca de l’Alta Ribagorça: des d'Erta a Peranera i a Malpàs
}

Josep Maria Mata-Perelló

Joaquim Sanz Balagué

\section{XARAGALL \\ REVISTA DE CIÈNCIES DE LA CATALUNYA CENTRAL}

ก. 9

SETEMBRE 2014 


\section{RECORREGUT DE RECERCA GEOLÒGICA I MINERALÒGICA PER LA COMARCA DE L'ALTA RIBAGORÇA: DES D’ERTA A PERANERA I A MALPÀS}

\section{Josep Maria Mata-Perelló}

Museu de geologia Valentí Masachs, Escola Politècnica Superior d'Enginyeria de Manresa (EPSEM), Universitat Politècnica de Catalunya · BarcelonaTech (UPC), 08272 Manresa, Spain

\section{Joaquim Sanz Balagué}

Departament d'Enginyeria Minera i Recursos Naturals (EMRN), Escola Politècnica Superior d'Enginyeria de Manresa (EPSEM), Universitat Politècnica de Catalunya · BarcelonaTech (UPC), 08272 Manresa, Spain

Paraules clau: Sistema Pirinenc, Mantell de les Nogueres, Zona Axial Pirinenca, Materials mesozoics, Patrimoni miner

\section{Resum}

Itinerari realitzat el 22 de setembre de 2013. En aquesta ocasió, la totalitat del recorregut de I'itinerari es desenvoluparà per una sola unitat geològica: concretament pel Sistema Pirinenc i més exactament pel Mantell de les Nogueres, en la seva totalitat. Tot i així, en diversos trams centrals del recorregut ens aproparem molt (sense arribar a entrar-hi) a la Zona Axial Pirinenca, o més concretament pels denominats Apilaments antiformes de la Zona Axial Pirinenca.

Així, al llarg del recorregut, trobarem afloraments dels materials mesozoics (del Triàsic) i dels paleozoics (del Devonià, Carbonífer i Permià), que formen part de l'esmentat Mantell de les Nogueres. Aquests materials els anirem trobant al llarg de trot el recorregut de l'itinerari, entre la Mola d’Amunt i Malpàs.

Per d'altra banda, cal dir que aquest itinerari es desenvoluparà per dues de les comarques que configuren els Pirineus. Així, s'iniciarà dintre del Pallars Jussà, per on es circularà fins arribar a les immediacions d’Erta. Després, el recorregut entrarà a la comarca de l'Alta Ribagorça, per on es circularà entre Erta i Malpàs, per on finalitzarà el recorregut d’aquest itinerari. 


\section{Objectius fonamentals}

Es centraran en els aspectes geològics, geomorfològics i mineralògics que apuntarem a continuació:

1. Observació dels materials que constitueixen la Unitat de les Nogueres. Aquests materials pertanyen al Carbonífer (amb trams d'esquistos negres, fonamentalment) al Permotries (amb gresos rogencs), i sobretot al Triàsic, en tots els seus trams, especialment al Keuper (amb trams de guixos, argiles i ofites).

2. Observació de les relacions existents entre aquest unitat i la Zona Axial, situada al Nord del recorregut de l'itinerari, tot i que molt propera, en alguns indrets del recorregut central de l'itinerari.

3. Observació de les antigues explotacions, que anem trobant al llarg del recorregut de I'itinerari, com de explotacions dels materials carbonosos situats prop de Peranera i d'Erill Castell, dintre de la Formació Erill - Castell. Aquestes explotacions corresponen a les conegudes Mines de Malpàs.

4. Observació de l'impacte produït sobre el Medi Natural, com a conseqüència de les explotacions mineres acabades d'esmentar.

5. Observació dels indrets relacionats amb el patrimoni geològic i miner, que es vagin trobant al Ilarg del recorregut. En aquest sentit, cal fer esment de l'important Patrimoni Miner relacionat amb les Mines de Malpàs.

\section{Antecedents}

Pel que fa al recorregut del present itinerari, sols existeixen uns antecedents nostres, relatius a la primera part del recorregut de l'itinerari, pels voltants de la Mola d'Amunt i de Sentís, es les tracta de: Mata-Perelló (2009, 2010, 2013a, 2013b i 2013c). Pel que fa al tram central, entre Sentis i Peranera, no tenim cap antecedent. I pel que fa al tram final, pels voltants de Malpàs, hi ha diversos antecedents nostres, com: Mata-Perelló (2005a, 2005b, 2008a, 2008b, 2008c, 2010a, 2010b i 2012), fent esment dels treballs més recents.

Pel que fa a la descripció de les mineralitzacions, cal parlar d'un altre treball, també nostre; en concret de Mata-Perelló (1991). Aquest treball es relatiu a les mineralitzacions catalanes en general, amb un capítol dedicat a la Noguera. També cal fer esment de Mata-Perelló i Sanz (1993).

I pel que fa a l'estructura geològica de la zona per la qual discorre l'itinerari, farem esment de dos treballs, molt interessants, de caràcter generalista. En concret, ens estem referint als següents: Guimerà et altri (1982). i també a Riba et altri (1976). Tots dos treballs es refereixen a la geologia dels Països Catalans, i conseqüentment de Catalunya. Per d'altra banda, també cal fer esment del treball de Rosell (1970); així com de I'IGME (1994).

Tots aquests treballs referenciats, i d'altres, figuren esmentats per ordre alfabètic a l'apartat dedicat a la BIBLIOGRAFIA. 


\section{Recorregut de l'itinerari}

El recorregut de l'itinerari discorrerà inicialment per la comarca del Pallars Jussà, entre Erta i la fi del recorregut, prop de Malpàs, es circularà per la comarca de l'Alta Ribagorça, per on finalitzarà el recorregut.

Així, el recorregut s'iniciarà a la localitat d'Erta, a la comarca de I'Alta Ribagorça. Des d'aquí, el recorregut continuarà cap a les immediacions de Peranera i cap a Castellars. Finalment, després d'arribar prop de Malpàs, el recorregut s'adreçarà cap a les Mines de Malpàs, per on finalitzarà. En aquest tram, es realitzaran diverses aturades.

\section{Advertiments previs}

Com en altres recorreguts de RECERCA GEOLÒGICA I MINERALÒGICA... si es disposa del temps suficient, poden efectuar-se passant per totes les parades i filloles. En cas contrari, recomanem prescindir de les anomenades PARADES - CONDICIONALS.

També cal tenir en conte que una part del recorregut final de l'itinerari, es realitzarà per camins de terra, per la qual cosa caldrà prendre les necessàries precaucions, en tot moment del recorregut. Cal dir, que algun tram serà força dolent, com el que va des de Sentis cap a Sas.

Cal tenir, com sempre, una cura molt especial de respecte a la natura, al llarg de tot el recorregut de l'itinerari, i també fora d'ell.

\section{Descripció de l'itinerari}

En aquest recorregut hem situat, com ja és habitual en tots els itineraris, una sèrie d'ESTACIONS o de PARADES, que anirem veient a continuació. En cada cas, els hi donarem una denominació que podrà correspondre a algun paratge proper. També indicarem el terme municipal i la comarca on es troba.

Per altra banda, en cadascuna de les parades, indicarem entre parèntesi el número del "Mapa Topográfico", a escala 1:50.000, on es troba situada la parada considerada. En aquesta ocasió sols utilitzarem dos fulls, concretament: el $\mathbf{2 1 3}$ (o del Pont de Suert) i el 214 (o de Sort).

Així doncs, la relació ordenada de les parades que composen aquest recorregut, és la següent. 


\subsection{Parada 1. RIUET DEL PORT D’ERTA, (Erta, actualment és del terme municipal de Pont de Suert i antigament era del terme de Malpàs, comarca de I’Alta Ribagorça). (Full 214).}

El recorregut l'iniciarem al petit poblet d' Erta, on podem arribar venint des de Sas. Després, ens caldrà continuar per la pista forestal que condueix cap a Castellars. A uns $1^{\prime} 5 \mathrm{Km}$ d'Erta, efectuarem la primera aturada, dintre del recorregut d'aquest itinerari.

En aquest recorregut, hem circulat dintre del Mantell de la Noguera. Així, haurem trobat afloraments dels materials mesozoics i dels paleozoics que formen part d'aquest mantell. Prop d'erta, haurem vist afloraments dels materials del Permotries (amb gresos rogencs) i del carbonífer (amb pissarres negres) fonamentalment.

Després, haurem trobat afloraments dels materials carbonatats (i dels pissarrencs, ocasionalment) del Devonià. Aquests materials carbonatats són els que apareixen per l'indret de l'aturada. Tot i que es troben recoberts per materials cenozoics, neògens del Pleistocè, de procedència glacial.

En aquest indret, es pot veure el riuet del Port d'Erta, el qual baixa de la coma del Port d'Erta, situada dintre del terme de Sarroca de Bellera. Cal dir que aquesta coma és en realitat un petit circ glacial, situat a unes 3 hores d'Erta, aigües amunt. (fotografies 1 i 2).

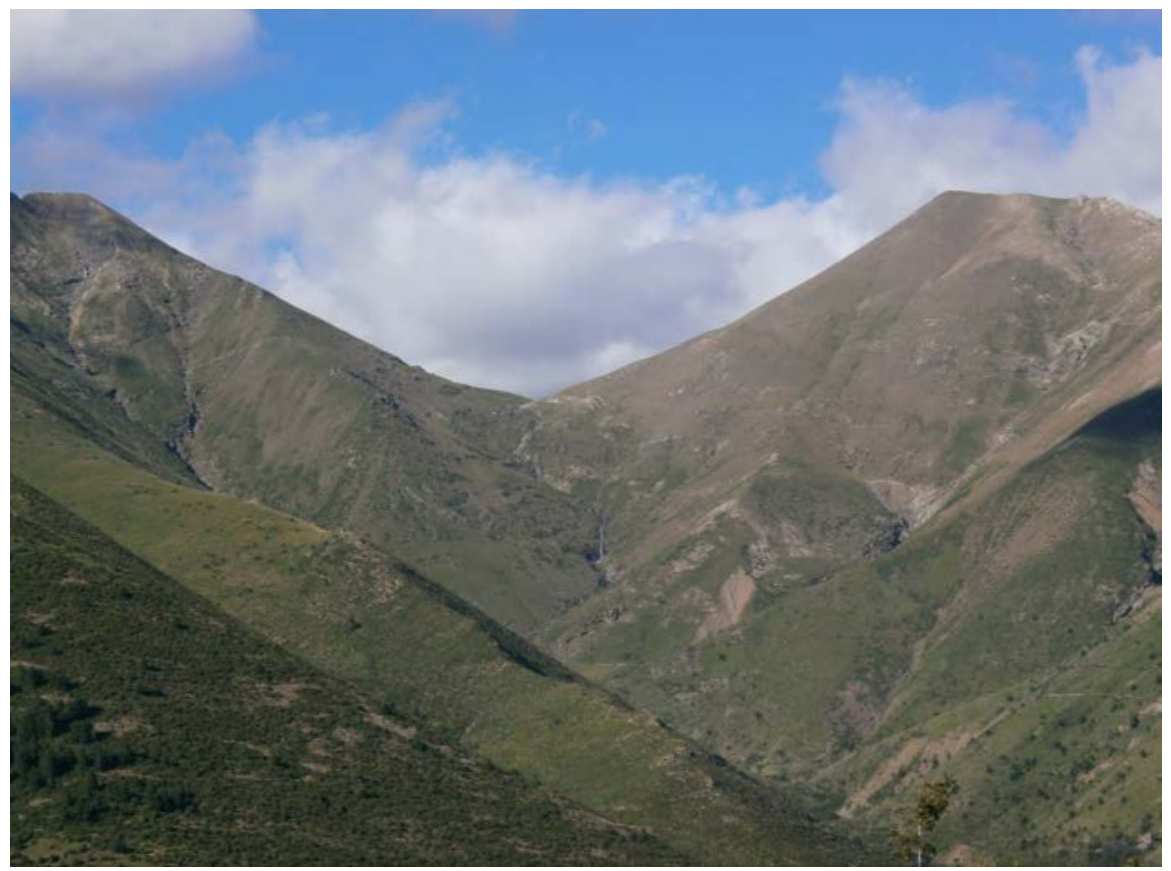

Fotografia 1. Pas d’Erta, entre afloraments de materials del Devonià. Al fons es fa evident el Circ d’erta 7 d’Agost del 2013 


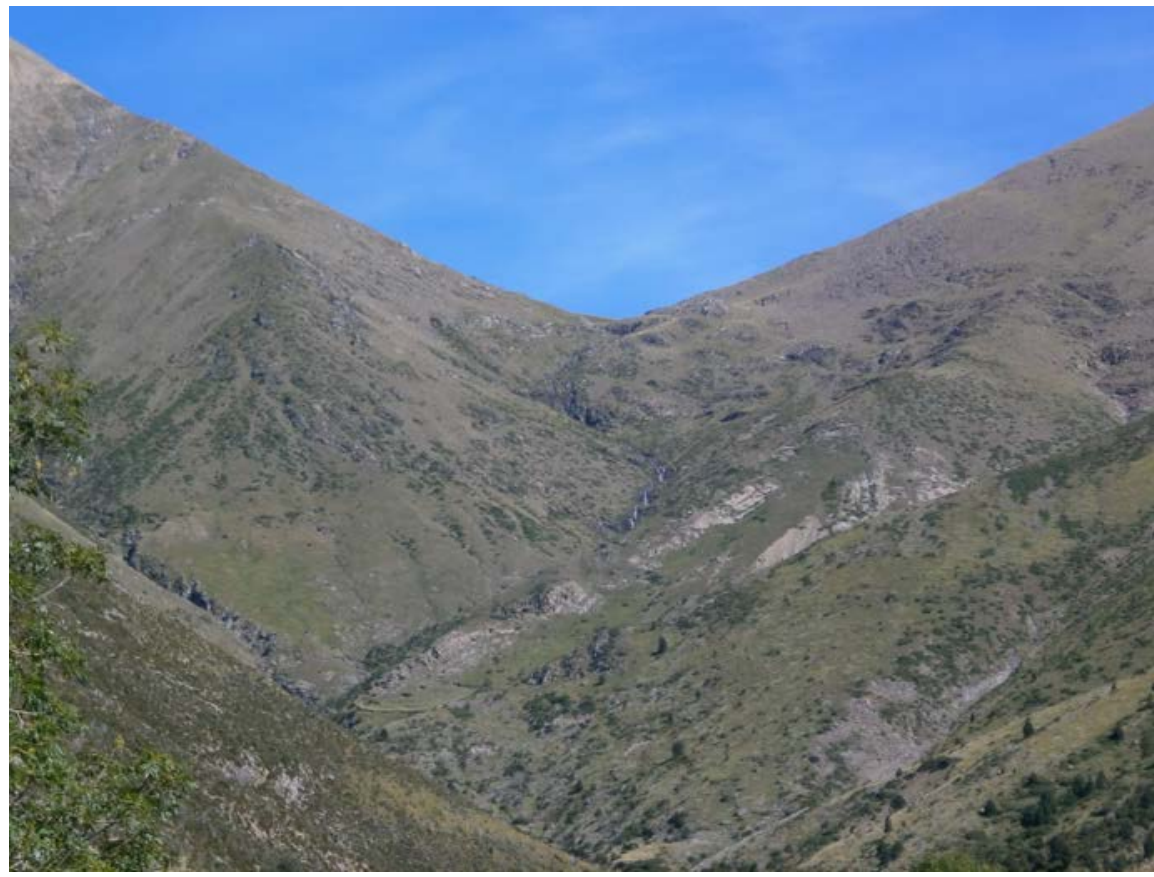

Fotografia 2. Un altre aspecte del Pas d'Erta, entre afloraments de materials del Devonià. Com a la fotografia anterior, es fa evident el Circ d'Erta / Setembre del 2013

\subsection{Parada 2 . COLL DE FADES, (Sas i Peranera; el primer actualment és del terme de Sarroca de Bellera, del Pallars Jussà i abans era del terme de Benes, de l'alta Ribagorça; el segon es actualment és del terme municipal de Pont de Suert i antigament era del terme de Malpàs, comarca de I’Alta Ribagorça). (Full 214).}

Des de la parada anterior, cal continuar ara el Sud, per la pista forestal que va conduint cap a Castellars. En arribar a les immediacions del Coll de Fades, podem realitzar una nova aturada, després d'efectuar un recorregut proper als $5 \mathrm{Km}$, des de la parada anterior.

En aquest recorregut, tot i que ens hem apropat molt a la Zona Axial Pirinenca, no hi hem arribat a entrar. En efecte, ens hem mogut en tot moment, dintre del Mantell de les Nogueres. En aquest tram, haurem anat trobant afloraments dels materials carbonatats del Devonià, en bona part del recorregut. Aquets són també els materials que apareixen prop de l'indret de I'aturada. Tot i així, es fan força evidents ara els trams de gresos rogencs del Permotries. Cal dir que en aquest coll, hem sobrepassat I'Encavalcament de Sas

En aquest recorregut, hem gaudit d'una bona observació de les valls del riu Peranera (situada a ponent) i del riuet del Port d'Erta /situada a llevant). Des d'aquest indret, per on efectuem la present aturada, podem efectuar aquesta mateixa observació. (fotografía 3). 


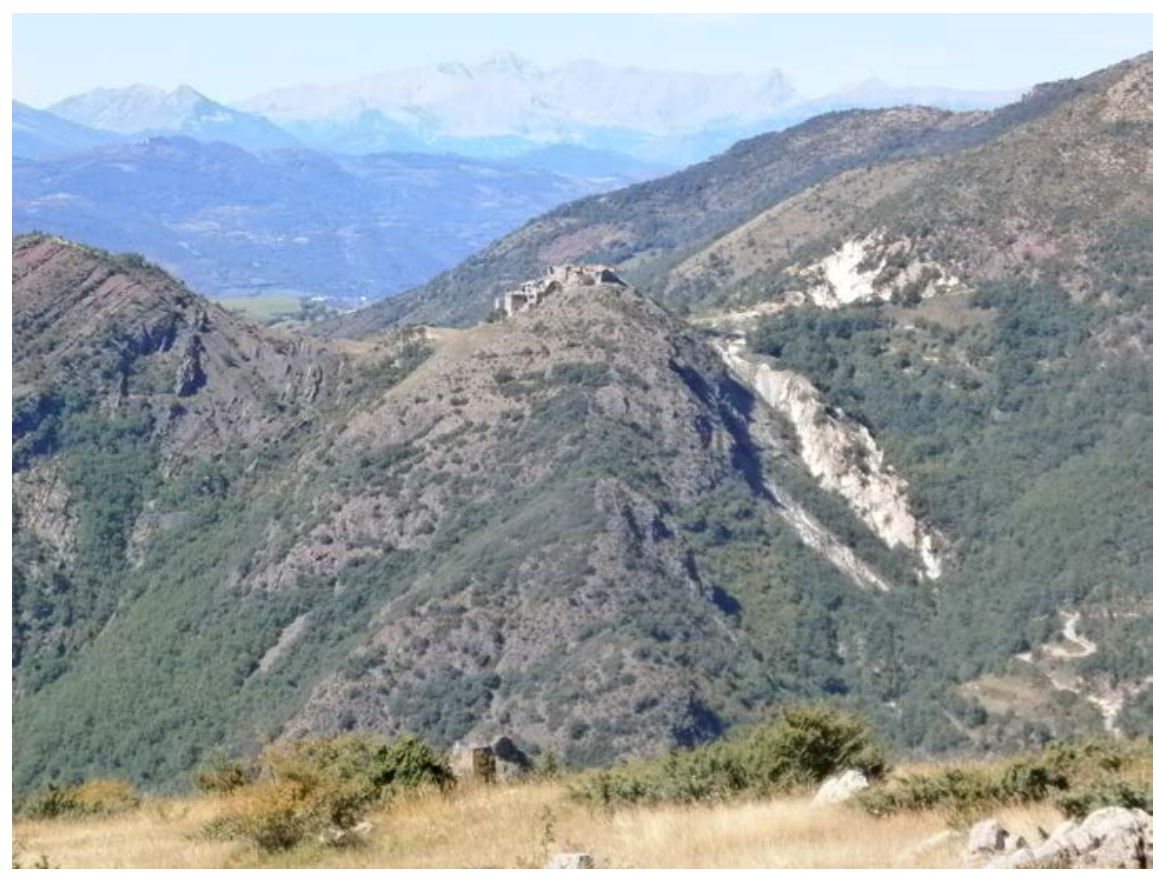

Fotografia 3. Un altre aspecte de la vall de la Nogera de Peranera. Cap el centre es veu el poble d’Erill - Castell, situat sobre un aflorament de roques volcàniques del Permià / Setembre del 2013

Igualment, des d'aquest indret, mirant cap a llevant, es pot veure el Coll de Sas, per on passa I'Encavalcament de Sas, situat prop del poble del mateix nom. Així, mirant cap a l'esmentat coll, es pot observar una repetició dels afloraments dels materials del permotries. (fotografia 4).

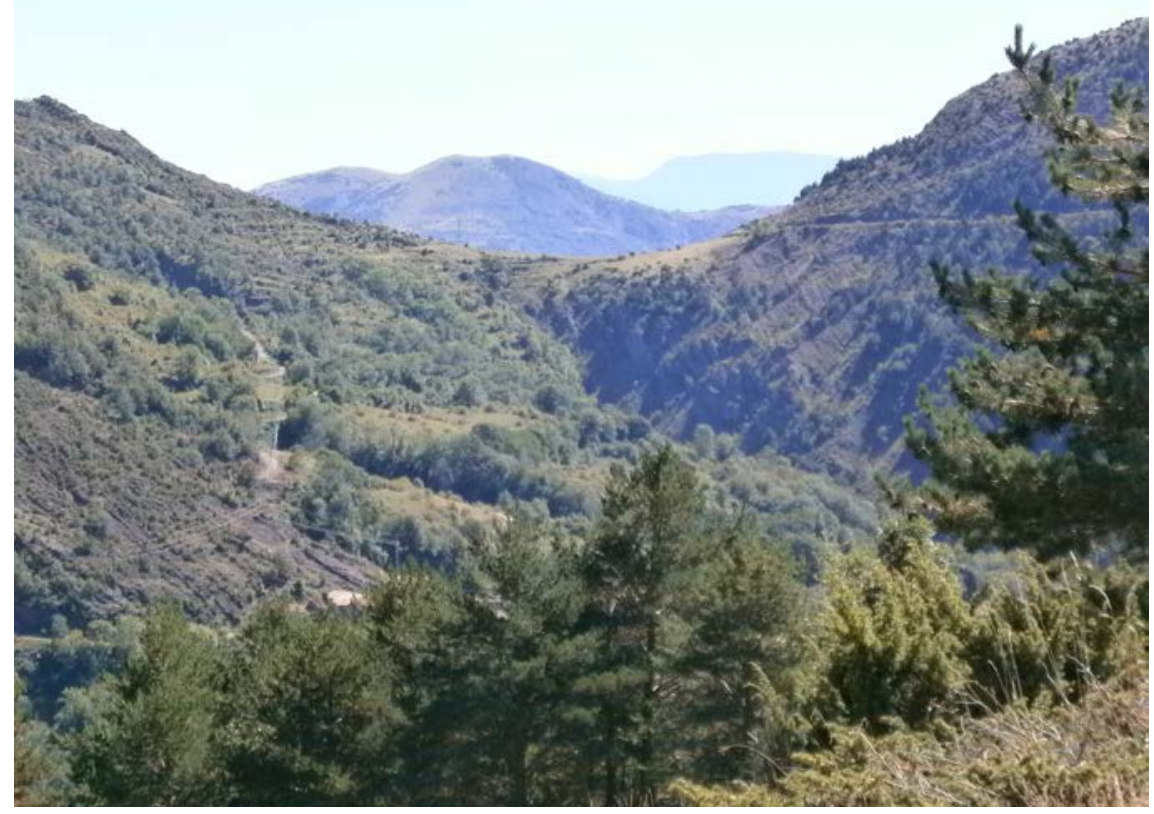

Fotografia 4. Un altre aspecte del Coll de Sas, per on discorre l'Encavalcament de Sas. A la dreta hi afloren el materials del Permotries i els del carbonifer. I a l'esquerra també, però encavalcant als anteriors / Setembre del 2013 


\subsection{Parada 3 - CONDICIONAL. COLL DE PERANERA, (Peranera, actualment és del terme municipal de Pont de Suert i antigament era del terme de Malpàs, comarca de l’Alta Ribagorça). (Full 214).}

Des de la parada anterior, cal continuar ara el Sud, per la pista forestal que va conduint cap a Castellars. En arribar a les immediacions del Coll de Peranera, podem realitzar una nova aturada, després d'efectuar un recorregut proper als $1^{\prime} 2 \mathrm{Km}$, des de la parada anterior.

En aquest recorregut. Hem continuat trobant afloraments dels materials esmentats a les aturades anteriors. Així, ara haurem vist afloraments dels materials del Permotries i del carbonífer. Tot i així, en aquest indret, haurem sobrepassat l'encavalcament de Peranera, similar i paral.lel a l'encavalcament de Sas, que hem vist a l'aturada anterior. Així, abans de creuar el Coll de Fades, a la parada anterior, haurem vist afloraments dels materials del Devonià, però ben aviat haurem trobat els afloraments dels materials del Permotries i els del carbonífer, que són els que apareixen a l'indret de l'aturada.

\subsection{Parada 4. TREMUGES DE LES MINES DE MALPÀS, (Malpàs, actualment és del terme municipal de Pont de Suert i antigament era del propi terme de Malpàs, comarca de l’Alta Ribagorça). (Full 213).}

Des de la parada anterior, cal fer un nou recorregut, per tal d'arribar a les immediacions del poble Castellars (per on no arribarem a passar) i posteriorment a les immediacions del poble de Malpàs. Poc abans d'arribar a aquest darrer poble, trobarem una cruïlla i ens caldrà seguir pel camí que remunta per la dreta el barranc de Peramera, el camí que es dirigeix cap a les antigues Mines de Malpàs i que posteriorment es dirigeix cap a I'antic poble d'Erill-Castell, situat enfront del de Peranera. En arribar a les esmentades mines; i concretament a les tremuges, farem una nova aturada, aproximadament a uns $5 \mathrm{Km}$ de la parada anterior.

En aquest recorregut, bona part del qual s'ha anat fent de baixada, hem estat circulant sempre dintre del Mantell de les Nogueres. En principi, haurem trobat els afloraments dels materials del Permotries i del triàsic. Així, prop de Castellars s'hauran fet palesos els afloraments dels guixos $\mathrm{i}$ de les argiles triàsiques del Keuper. Tanmateix, prop de la carretera, es fan palesos afloraments de les ofites del Keuper.

Més avall, prop de l'indret de l'aturada, tornarem a trobar afloraments dels materials rogencs del Permotries (amb nivells de gresos, fonamentalment). Aquests són els materials que apareixen prop de la cruïlla, d'on eix el camí cap a les antigues mines. També són els que apareixen per les immediacions de Malpàs.

En aquest indret hi ha les antigues instal-lacions de càrrega, de les explotacions carbonoses, a les quals s'aprofitaven uns importants nivells d'hulles incloses entre els materials del Carbonífer Superior i del Pèrmic, els quals pertanyen a la denominada Formació Malpàs, que apareix pels voltants de les instal-lacions mineres.

Així, s' hauran fet paleses les escombreres de les antigues mines de carbó, situades a la bora de la carretera, prop del trencall del camí que condueix cap el poblet enlairat d’Erill - Castell

Entre aquestes instal-lacions es fan força paleses les tremuges externes de les Mines de Malpàs. (fotografia 5). 


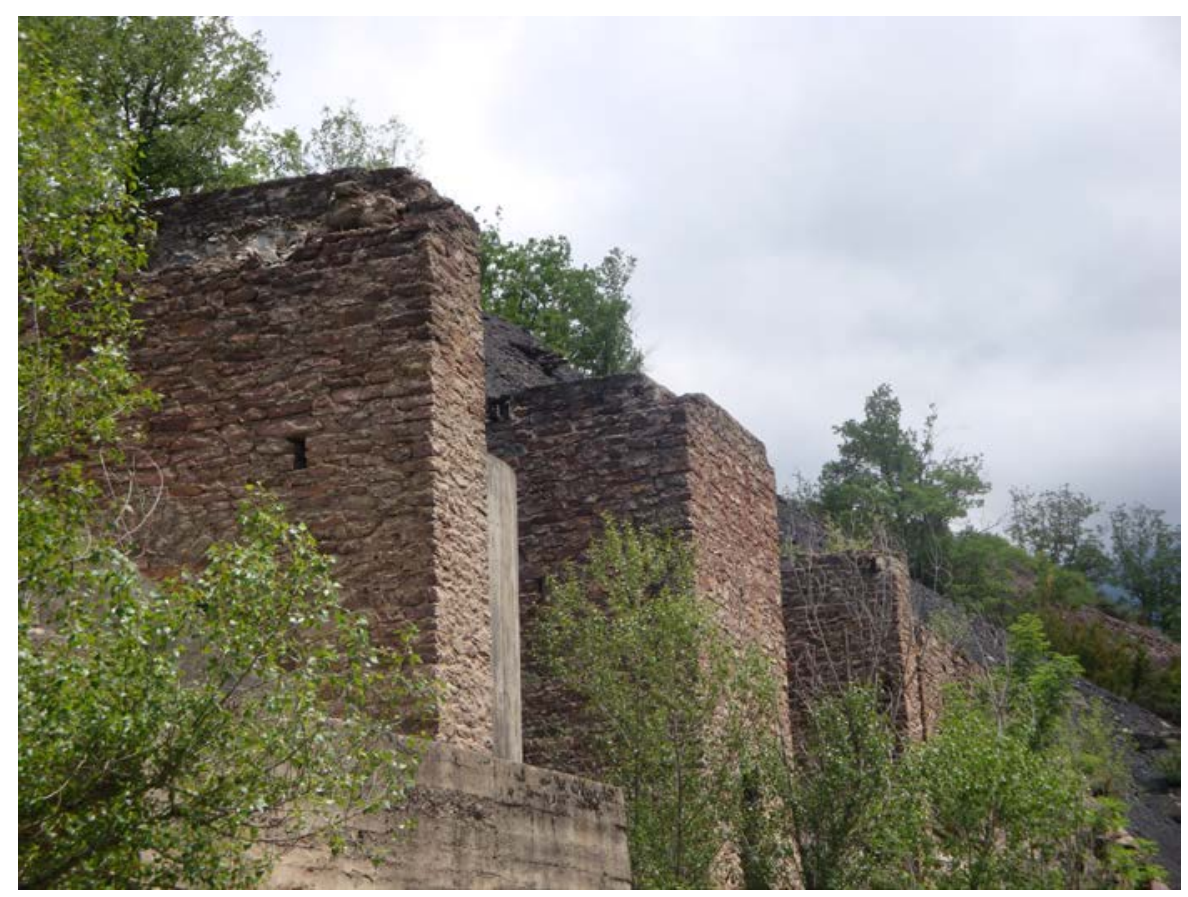

Fotografia 5. Tremuges externes de les Mines de Malpàs / Juny 2009

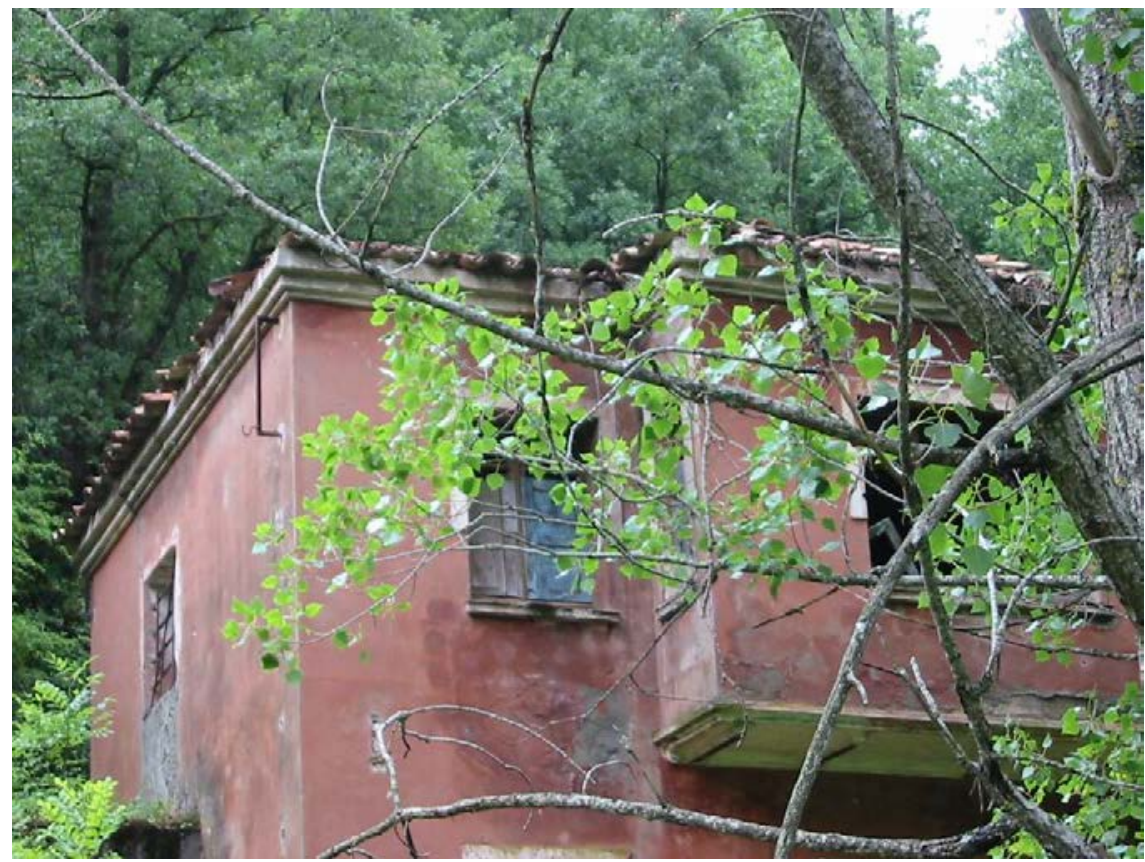

Fotografia 6. Edificis dels serveis de les Mines de Malpàs / Juny 2009 


\subsection{Parada 5. TREMUGES INTERNES DE LES MINES DE MALPÀS, (Malpàs, actualment és del terme municipal de Pont de Suert i antigament era del propi terme de Malpàs, comarca de l'Alta Ribagorça). (Full 213).}

Des de la parada anterior, cal fer un nou i breu recorregut, per tal d'arribar a la zona central de les antigues Mines de Malpàs. En arribar-hi, farem una nova aturada, a uns 300 metres de I'anteriorment efectuada.

En aquest recorregut, hem continuant trobant afloraments dels materials del Permotries. Tot $\mathrm{i}$ així, hem anat baixant dintre de la sèrie estratigràfica. Així, hem trobat afloraments dels materials del trànsit del Carbonífer al Permià, que són els que apareixen a l'indret per on farem la present aturada.

En aquest indret, hi ha les restes de les antigues instal-lacions de les Mines de Malpàs. Així, es fàcil veure on es trobaven les antigues oficines i serveis de les explotacions mineres. (fotografia $6)$.

Prop d'aquest indret, aigües amunt, es trobaven les antigues tremuges, des d'on sortia el telefèric cap a la fàbrica de ciment de Xerallo. Es veuen, per arreu, restes de les esmentades tremuges i dels túnels d’accés a les mateixes. (fotografies 7 i 8).

Prop d'aquest indret hi havia un pontet, des d'on sortia la explanada d'un ferrocarril miner, que anava conduint cap a les tremuges que hem vist a la PARADA 4. Cal destacar que el recorregut d'aquest ferrocarril miner era força interessant, amb túnels i ponts, arribant finalment a les esmentades tremuges. Així es podien salvar els barrancs i el turonets. Tenia quasi 0’ $5 \mathrm{Km}$ de recorregut.

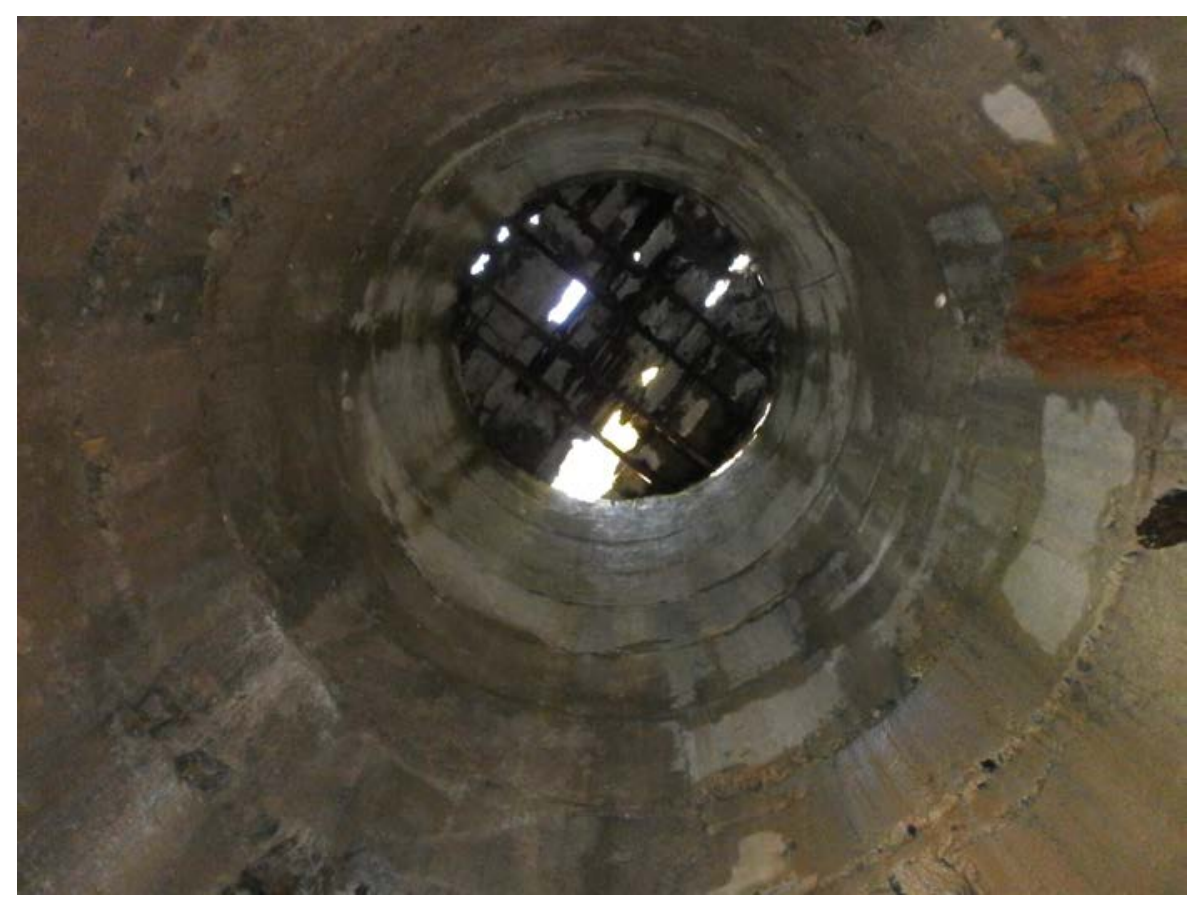

Fotografia7. Restes de les tremuges interiors / 7 d’Agost del 2013 


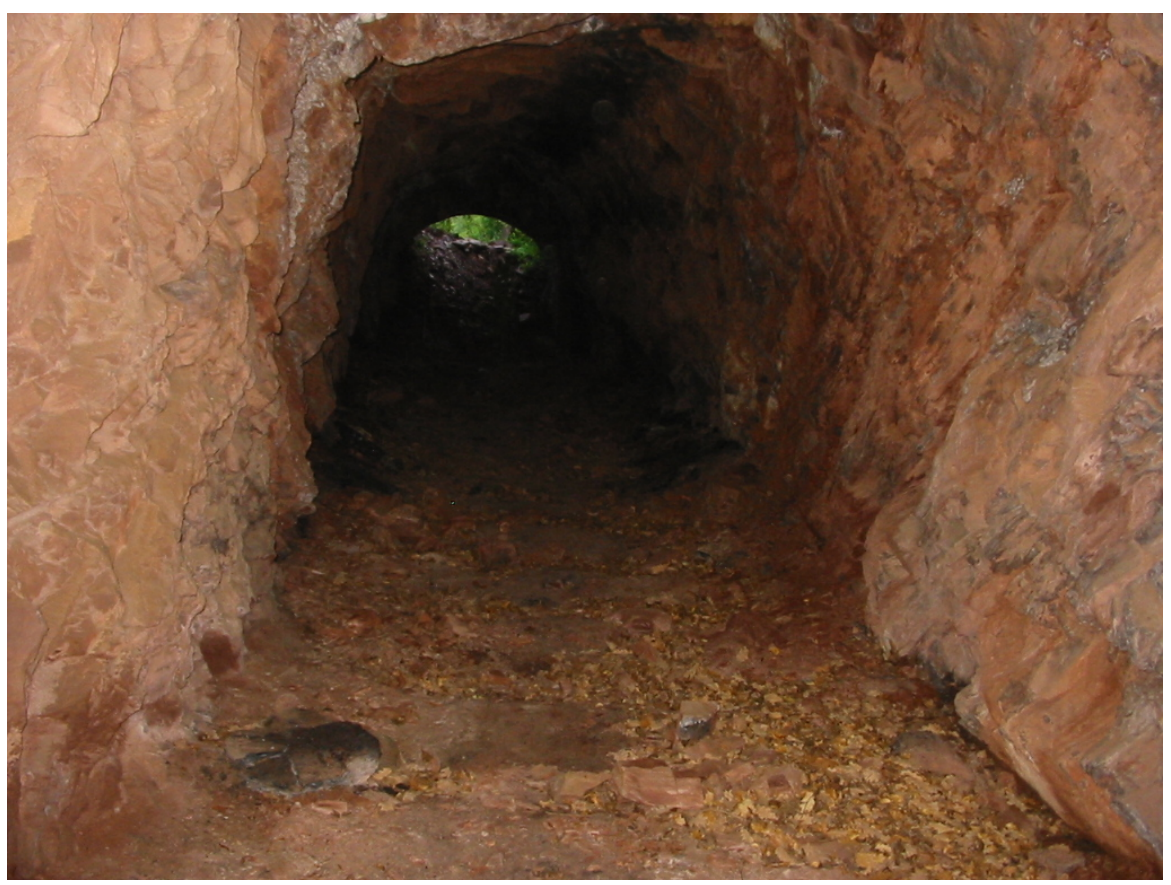

Fotografia 8. Túnel del ferrocarril miner / Juny 2009

\subsection{Parada 6. ANTIGUES EXPLOTACIONS DE LES MINES DE MALPÀS, DEL CAMÍ A ERILL CASTELL, (Malpàs, actualment és del terme municipal de Pont de Suert i antigament era del propi terme de Malpàs, comarca de l'Alta Ribagorça). (Full 213).}

Des de la parada anterior, cal fer un nou recorregut, pel camí que va ascendint cap al poblet aturonat de Erill Castell. Tot i així, a poca distancia de la parada anterior, a menys de 0’ $5 \mathrm{Km}$, començarem a trobar algunes escombreres prop del camí. Aquí farem una nova aturada, la darrera d'aquest itinerari.

En aquest recorregut, hem continuant trobant afloraments dels materials del trànsit del Carbonífer al Permià. Entre aquests materials es troben els nivells de les hulles explotades a la conca minera de Malpàs, concretament a les Mines de Malpàs. FOTOGRAFIA 9 i 10. Entre les hulles es troben diverses mineralitzacions eminentment ferruginoses, amb presència de: MARCASSITA. MELNIKOWITA (indicis), PIRITA (abundant, i sovint ben cristal-litzada), GOETHITA (limonítica), HEMATITES (poc abundant), SIDERITA (indicis), MELANTERITA i SIDEROTÍL. Amb els anteriors, també es troben altres minerals com: SOFRE (indicis), CALCITA, GUIX, CAOLINITA i QUARS, entre altres.

Finalment, també, cal dir que aquestes mines eren les més importants de la denominada Conca Hullera de Malpàs, que s'estén per diverses localitats de I'Alta Ribagorça (Erill-Castell i Peranera), i també del Pallars Jussà (com: Avellanos, Erdo, Guiró, Oveix, Sas i Vilancos). Finalment, cal dir que les darreres explotacions, situades en aquest indret, es van tancar a finals dels anys seixanta, just després de la construcció de les grans presses situades al llarg del Noguera Ribagorçana. 


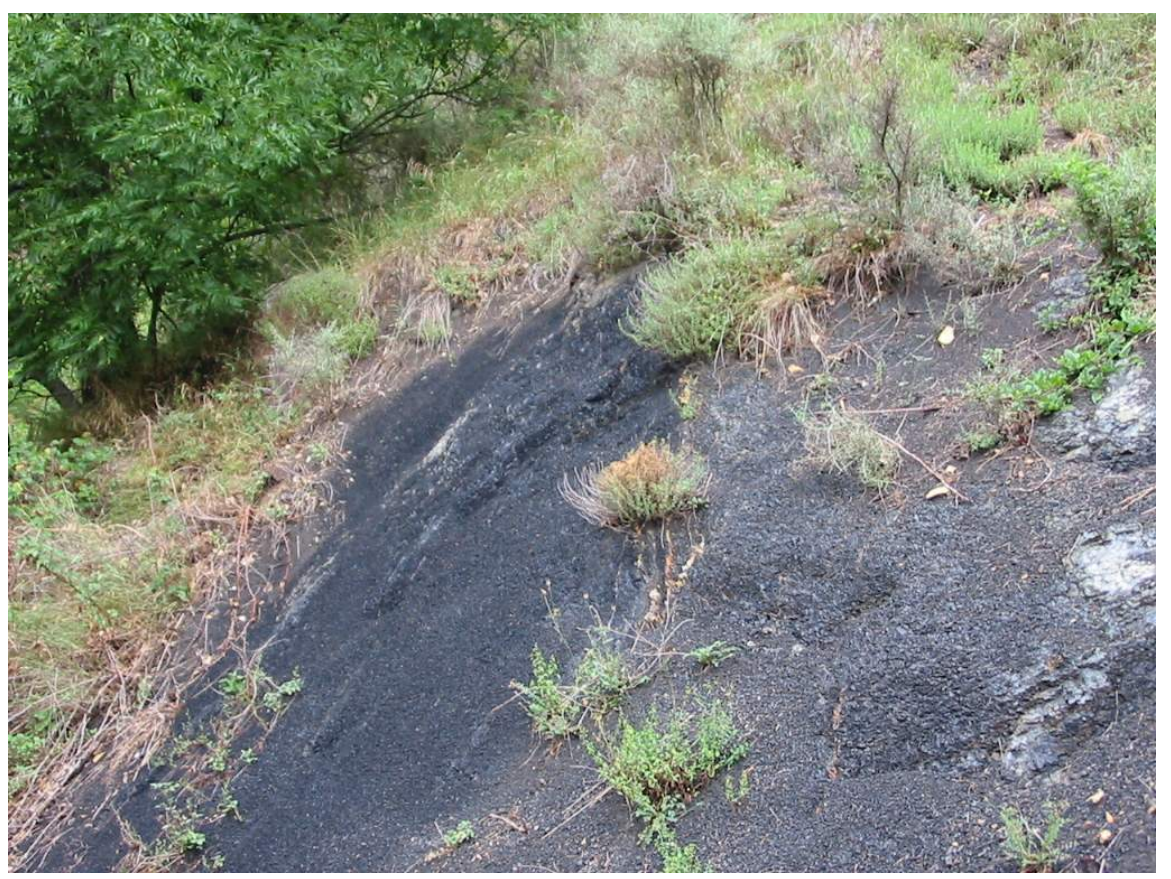

Fotografia 9. Escombreres de les explotacions dels nivells carbonosos al camí - carreter de Malpàs a Erill Castell. En aquestes escombreres es troben diversos restes fòssils. / Juny 2009

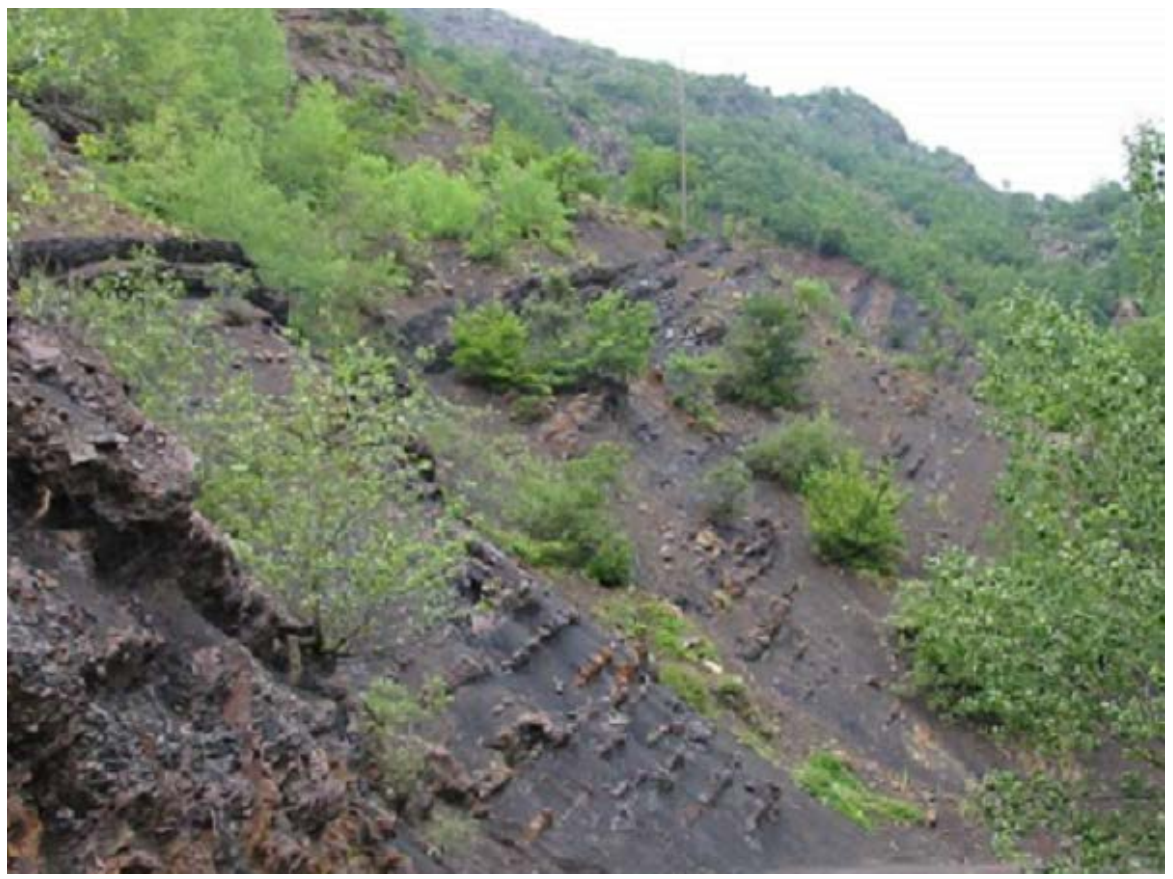

Fotografia 10. Afloraments dels nivells carbonosos al camí - carreter de Malpàs a Erill Castell / Juny 2009

En aquest indret finalitza el recorregut de l'itinerari.

Xaragall.2014 n.9 | Recorregut de recerca geològica i mineralògica per la comarca de I’Alta Ribagorça: des 


\section{Bibliografia}

GUIMERÀ, J. et altri (1992).- Geologia (II), Història Natural dels Països Catalans, Vol. 2, 547 pag. Enciclopèdia Catalana, S.A. Barcelona.

IGME (1994).- Mapa Geológico de España a escala 1:50.000 (Plan Magna). Fulla i Memòria nº 252 (Tremp). Inst. GeoMinero y Tecnol. España. Minist. Indústria. Madrid.

MATA-PERELLÓ, J.M. (1991).- Els Minerals de Catalunya. Arxius de la Secció de Ciències de I'Institut d'estudis Catalans, vol.47, 545 pàgines. Barcelona.

MATA - PERELLÓ, J. M. (2005a).- Recorregut de recerca geològica i mineralògica per les comarques del Pallars Jussà i de I'Alta Ribagorça: des de Senterada a Xerallo, la Vall de Manyanet i al Pont de Suert. Inèdit. 10 pàgines. Manresa.

MATA - PERELLÓ, J. M. (2005b).- Recorregut de recerca geològica i mineralògica per la comarca de l'Alta Ribagorça i per la Vall de Benasc: des de Malpàs i Vilaller a Montanui, al Pic Galliner i a Cerler. Inèdit. 8 pàgines. Manresa.

MATA - PERELLÓ, J. M. (2008a).- Recorregut de recerca geològica i mineralògica per les comarques de la Vall de Benasc i de l'Alta Ribagorça: des de Castejón de Sos a Malpàs. Inèdit. 6 pàgines. Manresa.

MATA - PERELLÓ, J. M. (2008b).- Recorregut de recerca de geològica i mineralògica per les comarques de I'Alta Ribagorça: des de la Pressa de Cavallers a Pont de Suert i a Malpàs. Inèdit. 8 pàgines. Manresa.

MATA - PERELLÓ, J. M. (2008c).- Recorregut de recerca geològica i mineralògica per la comarca de la Ribagorça: des de Malpàs a Estet Inèdit. 8 pàgines. Manresa.

MATA-PERELLÓ, J.M. (2009).- Recorregut de recerca geològica i mineralògica per les comarques del Pallars Jussà i de l'Alta Ribagorça: des de Senterada a Xerallo i al Pont de Suert. Inèdit. 10 pàgines. Manresa.

MATA-PERELLÓ, J.M. (2010a).- Recorregut de recerca geològica i mineralògica per les comarques del Pallars Jussà i de l'Alta Ribagorça: des de la Pobla de Segur a Senterada, Xerallo i al Pont de Suert. Inèdit. 10 pàgines. Manresa.

MATA - PERELLÓ, J. M. (2010b).- Recorregut de recerca geològica i mineralògica per les comarques del Pallars Jussà i de l'Alta Ribagorça: des de la Pobla de Segur a Senterada, Xerallo i al Pont de Suert. Inèdit. 10 pàgines. Manresa.

MATA - PERELLÓ, J. M. (2010c).- Recorregut de recerca geològica i mineralògica per la comarca de la Ribagorça: des de Malpàs al Pont de Suert, Vilaller i a Estet. Inèdit. 8 pàgines. Manresa.

MATA - PERELLÓ, J. M. (2012).- Recorregut de recerca geològica i mineralògica per les comarques del Pallars Jussà i de l'Alta Ribagorça: des de Senterada a Xerallo i al Pont de Suert. Inèdit. 10 pàgines. Manresa.

MATA - PERELLÓ, J. M. (2013a).- Recorregut de recerca geològica i mineralògica per la comarca del Pallars Jussà: des de la Pobla de Segur a Senterada, Sarroca de Bellera, a Xerallo i a la Vall de Manyanet. Inèdit. 12 pàgines. Manresa.

MATA - PERELLÓ, J. M. (2013b).- Recorregut de recerca geològica i mineralògica per la comarca del Pallars Jussà: des de Xerallo a la Mola d'Amunt i a Manyanet. Inèdit. 10 pàgines. Manresa. 
MATA - PERELLÓ, J. M. (2013c).- Recorregut de recerca geològica i mineralògica per les comarques del Pallars Jussà i de l'Alta Ribagorça: des de la Mola d'Amunt a Sentís, Sas, Erta, Peranera i a Malpàs. Inèdit. 14 pàgines. Manresa.

MATA-PERELLÓ, J.M. i SANZ BALAGUÉ, J. (1993).- Guía de identificación de Minerales, adaptada fundamentalmente a la Península Ibérica. Parcir, Edic. Selectas, 243 pàgines. Manresa.

RIBA ARDERIU, O. et altri (1976).- Geografia Física dels Països Catalans. Edit Ketres. 211 pàgines. Barcelona.

ROSELL SANUI, J. (1970).- Explicació del Mapa Geològic, a escala 1:50.000, corresponent al full nº 252 (Tremp). Mapa Geológico de España. Inst. Geológico y Minero de España. Madrid. 